\title{
CITICOLINE AFFECTS SERUM ANGIOSTATIN AND NEUROSPECIFIC PROTEIN LEVELS IN PATIENTS WITH ATRIAL FIBRILLATION AND ISCHEMIC STROKE
}

\author{
A. A. TYKHOMYROV \\ T. V. GRINENKO', O. V. KURYATA ${ }^{2}$
}

${ }^{1}$ Palladin Institute of Biochemistry, National Academy of Sciences of Ukraine, Kyiv; ${ }^{2}$ State Establishment "Dnipropetrovsk Medical Academy of Health Ministry of Ukraine", Dnipro; ${ }^{3}$ Bingöl University, Bingöl, Turkey

凶e-mail: artem_tykhomyrov@ukr.net

Received: 22 May 2019; Accepted: 13 August 2019

Ischemic stroke is considered as one of the most frequent and severe complications of atrial fibrillation. The present study was undertaken to examine whether post-insult treatment with cytidine diphosphate-choline (CDP-choline, or citicoline) affects serum levels of the angiogenesis inhibitor angiostatin and neurospecific proteins as markers of brain damage in patients with cerebral ischemia associated with atrial fibrillation. Thirty-three patients with a diagnosis of acute ischemic stroke received citicoline sodium by intravenous infusions (1,000 mg daily for 14 days) in addition to the standard treatment (basic group). Twentyfive patients with the same pathologies, who received only standard therapy, were enrolled in the study as a control group. Serum content of angiostatin and neurospecific proteins, namely neurofilament heavy subunit $(N F-H)$ and glial fibrillary acidic protein (GFAP), was measured by immunoblotting at the basal level and after the treatment. Citicoline treatment caused significant decreases in serum levels of angiostatin (by 40\% vs. basal level, $P<0.05$ ), GFAP (by 61\%, P<0.01), and the NF-H subunit (by 19\%, $P<0.05$ ) and had no effect on the serum albumin content. In contrast, there were no statistically significant differences between baseline levels of the studied protein markers and their content after the treatment period in the control group. These findings indicate for the first time that CDP-choline protects both astrocytes and neurons and improves angiogenic capacity through down-regulation of angiostatin in post-ischemic patients with atrial fibrillation after acute ischemic stroke. Further studies are needed to test associations between serum levels of these biomarkers, clinical outcomes, and treatment efficacy of stroke.

Ke y wo rds: atrial fibrillation, ischemic stroke, citicoline, angiostatin, neurofilaments (NFs), glial fibrillary acidic protein (GFAP).

I schemic stroke is a complex multifactorial and polygenic disease. It is generally accepted that one of the major risk factors for ischemic stroke is atrial fibrillation [1]. Past studies indicate that fibrillation of the atrium produces stasis of blood, which causes thrombus formation and embolism in the brain [2,3]. More recent investigations suggest that the pathogenesis of stroke in atrial fibrillation is more complicated and involves other factors in addition to the dysrhythmia $[4,5]$. It is well acknowledged that atrial fibrillation is the most prevalent car- diac arrhythmia, affecting approximately $1-2 \%$ of the population worldwide. Being an independent risk factor for stroke, atrial fibrillation is associated with high mortality, morbidity, and socioeconomic burden [6]. Therefore, stroke prevention with appropriate prophylaxis remains central to management of both atrial fibrillation and its neurological complications. However, the search for effective neuroprotectors remains frustrating, and the current therapeutic protocols remain suboptimal. Ideally, sufficient protection must be provided to the ischemic brain along with

(C) 2019 Tykhomyrov A. A. et al. This is an open-access article distributed under the terms of the Creative Commons Attribution License, which permits unrestricted use, distribution, and reproduction in any medium, provided the original author and source are credited. 
enhanced recovery of the damaged region. There is a need to protect the entire neurovascular unit, which is built of neurons, glia, and blood vessels [7].

From these points of view, citicoline, or cytidine diphosphate-choline (CDP-choline) (Fig. 1), can be regarded as one of the most promising agents for reducing ischemic stroke injury to the brain [8]. Citicoline is a naturally occurring compound, which is a key intermediate in the biosynthesis of phosphatidylcholine, an important component of the neural cell membrane. Cytidine and choline pass separately through the blood-brain barrier (BBB), enter brain cells, and act as substrates for intracellular synthesis of CDP-choline. Citicoline is widely available in many countries as an approved safe drug for the treatment of neurological disorders and is sold as a dietary supplement. As a drug, citicoline has been proposed for use in traumatic brain injuries, vascular dementia, Parkinson's disease, and brain aging, where it stabilizes cell membranes, reduces the level of oxidative stress, and acts as an anti-apototic agent [9]. It has been extensively tested in many stroke studies and has shown promising results with regard to the reduction of infarct size and improvement of functional recovery, although the exact mechanisms through which it operates are not fully understood [10]. Some evidence points to the ability of citicoline to normalize neurotransmitter release patterns. In several animal models, citicoline has been shown to inhibit the impairment of neurotransmitter release in hypoxic conditions [11]. Other studies have found that citicoline is able to increase the dilation of blood vessels in animals with cerebral microcirculation injury, thereby significantly increasing cerebral blood flow [12]. Additional mechanisms through which citicoline may promote neuroprotective effects should be clarified. Therefore, searching for reliable markers of citicoline treatment efficacy is still an important goal for research studies.

Though a single biomarker for ischemic stroke is currently not used in clinical practice, efforts to develop a test battery are ongoing because it would be valuable for supporting a clinical diagnosis of stroke, identifying patients at risk for disease, and guiding treatment and prognosis. Molecular indexes of brain tissue damage, inflammation, endothelium, and coagulation/thrombosis may play a potential marker role [13]. Due to ischemia-induced cell damage and BBB disruption, some specific proteins are released from neurons and glial cells into the bloodstream, and represent plausible markers for the diagnosis

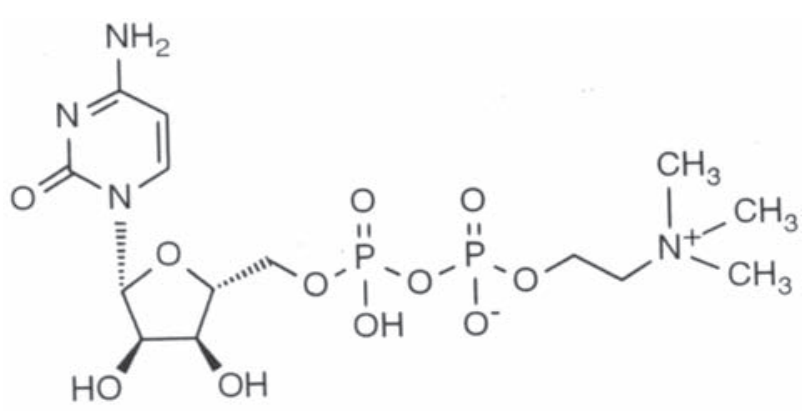

Fig. 1. Cytidine diphosphate-choline (CDP-choline, or citicoline)

and prognosis of patients with ischemic stroke [14]. Among all CNS molecules, specific cytoskeletal proteins are the most reliable candidates for the role of biomarkers of brain injury because of their exclusive expression in neurons or glial cells and relative stability to proteolytic degradation in the bloodstream [15]. Numerous studies indicate that glial fibrillary acidic protein (GFAP), a specific protein of astroglial cells, can serve as a sensitive and valuable marker for brain damage as well as an index of neuroprotective efficacy [16]. After cerebral ischemia, astrocytes undergo a vigorous response called astrogliosis characterized by increasingly higher GFAP expression. Astrogliosis may have both beneficial and detrimental effects on injured brain. It promotes neuronal repair and survival by increasing production of trophic factors. However, reactive astrocytes can form a glial scar that obstructs axonal regeneration and communication [17]. In humans, elevated serum GFAP concentrations reflect astrogliosis induced by intracerebral hemorrhage, acute cerebral stroke and traumatic brain injury, when GFAP moves into the circulation via the damaged BBB [16, 18]. Neuronderived markers of ischemic stroke can be represented by neurofilament (NF) proteins, which are known as highly specific constituents of neuronal intermediate filaments and play an important role in the modulation of axonal calibre and transport. NFs are composed of three subunits with different molecular weights, namely low (NF-L, $70 \mathrm{kDa}$ ), middle (NF-M, $160 \mathrm{kDa}$ ), and heavy (NF-H, $200 \mathrm{kDa}$ [19]. Several studies specify serum NFs as markers of axonal injury, axonal loss, and neuronal death, and address their diagnostic and prognostic roles in neurological disorders, including acute ischemic stroke and transient ischemic attack $[20,21]$. Thus, NFs have recently emerged as "universal" biomarkers of neurodegeneration. 
A single biomarker or even a group of biomarkers may not be able to sufficiently reflect the underlying complexity of ischemic stroke. For example, the BBB restricts release of ischemic brain biomarkers into systemic circulation. As a result, biomarker levels may not correlate with infarct volume or stroke severity. In this context, angiogenesis markers attract special attention, because neovascularization in ischemic brain is critical for the development of new microvessels and leads to re-formation of collateral circulation, reperfusion, enhanced neuronal survival and improved recovery [22]. It is widely accepted that angiogenesis is tightly controlled by a balance of proangiogenic and antiangiogenic factors. One of the most potent proangiogenic modulators, vascular endothelial growth factor (VEGF), is up-regulated by focal cerebral ischemia not only in animal models but also in human patients, and it has pleiotropic protective effects on brain function [23]. The association of VEGF-D with atrial fibrillation and stroke remains unclear, but in some studies increased VEGF-D concentrations were associated with atrial fibrillation and ischemic stroke [24]. Earlier, Gutiérrez-Fernández et al. [25] have shown that CDP-choline treatment of rats with the experimental model of the acute phase of cerebral infarct increases VEGF values in the peri-infarct zone compared with the infarct group.

Angiostatin, a proteolytic fragment of plasminogen/plasmin, plays a role in the local balance of angiogenesis and shows potent anti-angiogenic activity working via inhibiting endothelial cell division and migration, inducing apoptosis and counteracting VEGF proangiogenic signalling [26]. Unlike VEGF expression, little is known about angiostatin production and involvement in vessel growth regulation in the ischemia-injured brain. Nevertheless, increased formation of angiostatins in parallel with the reduced expression of VEGF in some ischemic tissues explains, at least partially, aberrant reparative angiogenesis and suppressed collateral formation in diabetes mellitus [27]. It has been hypothesized that angiostatin up-regulated levels correlate significantly with reduced angiogenesis and poorly developed cardiac collateral vasculature [28]. The most recent study of El-Ashmawy et al. [29] has demonstrated that elevated levels of another angiogenesis suppressor, endostatin, are associated with coronary artery calcification in type 2 diabetic patients. In our previous studies, we have shown the possibility of pharmacological targeting of circulating angiosta- tin levels by L-arginine and simvastatin in patients with coronary heart disease and chronic heart failure $[30,31]$. To our knowledge, no prior studies have examined effects of CDP-choline on angiostatin levels in ischemic stroke associated with atrial fibrillation. Therefore, this study was aimed to assess the effects of CDP-choline treatment on the serum levels of specific brain-derived proteins (NFs and GFAP) and a circulating angiogenesis inhibitor (angiostatin) in patients with ischemic stroke associated with atrial fibrillation.

\section{Materials and Methods}

Chemicals and antibodies. All chemical used were of analytical reagent grade quality and purchased from Sigma-Aldrich (USA), except for those specified in the text. In order to evaluate potential protein biomarkers ascribing two major pathological patterns related to ischemic stroke (neurodegeneration and angiogenesis) by western blot, the following primary antibodies were used: rabbit anti-GFAP (Santa Cruz Biotechnology, Inc., Dallas, TX, USA, sc-9065) and rabbit anti-neurofilament 200 (SigmaAldrich, St. Louis, MO, USA, N4142). Anti-angiostatin and anti-human serum albumin (HSA) antibodies were produced in rabbits and characterized as described elsewhere [32]. Goat anti-rabbit IgG (Sigma-Aldrich, A0545) secondary HPR-conjugated antibodies were also used.

Patients. All patients were randomly assigned to two groups: basic or control. Both groups of patients were representative by their general clinical indications. Thirty-three patients $(20$ men and 13 women; mean age: 76 years, min-max 67-79) with atrial fibrillation and ischemic stroke received citicoline sodium ("Ronocit", World Medicine, UK) in addition to standard treatment with anticoagulant and antiaggregant drugs (basic group). Citicoline was administered intravenously as slow intravenous infusions (40-60 drops per minute), $1000 \mathrm{mg}$ daily during the period of treatment throughout 14 days. Twenty-five patients (13 men and 12 women; mean age: 67 years, min-max 64-77) with atrial fibrillation complicated by ischemic stroke who received only standard therapy of anticoagulant and antiaggregant drugs were enrolled in the study as a control group. There were no significant differences $(P>0.05)$ in age or sex between these two groups. Exclusion criteria for the patients enrolled in the study were as follows: recent acute myocardial infarction $(<3$ months), acute coronary syndrome, and hematologic 
or oncologic diseases. Informed written consent was obtained from all patients before their participation in the study. The investigation conforms to the principles outlined in the latest revision of the Helsinki Declaration. All study procedures and protocols used in the investigation were reviewed and approved by the Ethical Committee of the State Establishment "Dnipropetrovsk Medical Academy", Ministry of Health of Ukraine (protocol no. 6, 07/02/2018).

Blood collection and sample preparation. After overnight fasting, baseline blood samples of each subject were drawn from their antecubital vein and collected in BD Vacutainer venous blood collection tubes (Becton, Dickinson and Company, Franklin Lakes, NJ, USA) containing a clot activator. Blood samples from the control and citicoline-treated patients were collected after overnight fasting the day after the last administration of citicoline. Blood was allowed to form a clot at room temperature for 30-60 min, and then centrifuged at $3,000 \mathrm{~g}$ for $10 \mathrm{~min}$ at $15{ }^{\circ} \mathrm{C}$ to separate the serum. Analysis of the biochemical parameters was performed without freezing, while $1 \mathrm{~mL}$ of serum samples was aliquoted and immediately frozen at $-20{ }^{\circ} \mathrm{C}$ until examination of the biomarkers.

Concentration of total serum protein was measured spectrophotometrically by the Stoscheck method [33]. Values of general laboratory and clinical parameters were assayed by routine analytical techniques.

Western blot. Serum samples were diluted 1:5 with SDS-containing electrophoretic sample buffer. For detection of all proteins of interest, except angiostatin, sample buffer was supplied with $10 \%$ $\beta$-mercaptoethanol. Equal amounts of proteins were fractionated by $10 \%$ SDS-PAGE and transferred onto nitrocellulose membranes, which were blocked in a $5 \%$ solution of non-fat dry milk and incubated with primary antibodies overnight at $4{ }^{\circ} \mathrm{C}$. After washing in phosphate buffered saline containing $0.05 \%$ Triton X-100 (PBST), the membranes were incubated with corresponding secondary antibodies for $90 \mathrm{~min}$ at $37{ }^{\circ} \mathrm{C}$ followed by several washes in PBST. Then, specific immunostaining was developed by enhanced chemiluminescence detection by incubation with HPR substrate. Protein bands were visualized, digitized, and quantified by "TotalLab" software (version 120) (TotalLab Ltd., USA). The results were expressed as units of optical density $x$ band area and termed as arbitrary units.

Statistical analysis. The summarizing statistics of protein marker levels are presented as 'box with whiskers' plots. Box plots display mean values, medians, extreme values, $25-75 \%$ quartile range, and standard deviations (SD). Quantitative data of laboratory parameters are shown as mean values $\pm \mathrm{SD}$. Paired student $t$-test was used to compare data between the two groups. All analyses were performed with "OriginPro" software (version 8.6, OriginLab Corporation, Northampton, MA, USA). For all tests, $P<0.05$ was considered statistically significant.

\section{Results and Discussion}

Physiological parameters remained unchanged throughout the period of treatment procedures and there were no significant statistical differences between groups, except for the glomerular filtration rate which was slightly increased in the citicolinetreated group (Table).

Unlike routine clinical parameters, serum levels of the studied protein markers appeared to be significantly changed as a result of citicoline-based therapy. Serum content of both neurospecific proteins was reduced after citicoline treatment. The most significant decrease was observed for the GFAP level (by $61 \%$ vs. basal level, $P<0.01$ ) (Fig. 2). It is worth noting that GFAP immunoreactive polypeptides detected in serum were represented not only by the intact subunit (49 kDa), but also by partially cleaved polypeptides in the range of $\mathrm{Mm} \sim 40-47 \mathrm{kDa}$. Fragmentation of GFAP in astrocytes is a well-known hallmark of reactive astrocytosis development [34].

However, it is unknown if GFAP fragments in serum came directly from brain or they appeared in circulation due to plasma proteolytic activities. GFAP levels demonstrate great intragroup variability that can be due to the different extents of BBB disruption or astrocytosis development. Citicolineinduced lowering of the NF heavy subunit (NF-H) level was not so pronounced as that of GFAP, but was shown to be also statistically significant (by $19 \%$ vs. basal level, $P<0.05$ ) (Fig. 3). Dramatic reduction was observed for the angiostatin level (by $40 \%$ vs. basal value, $P<0.05$ ) (Fig. 4). No changes in content of serum albumin, the most abundant serum protein, after citicoline treatment were demonstrated in the studied patients indicating CDP-choline to be safe in terms of liver protein synthetic capacity and kidney function (Fig. 5).

In contrast to the citicoline-treated group, there were no statistically significant differences between baseline levels of any detected protein markers and their content after the treatment period in the con- 


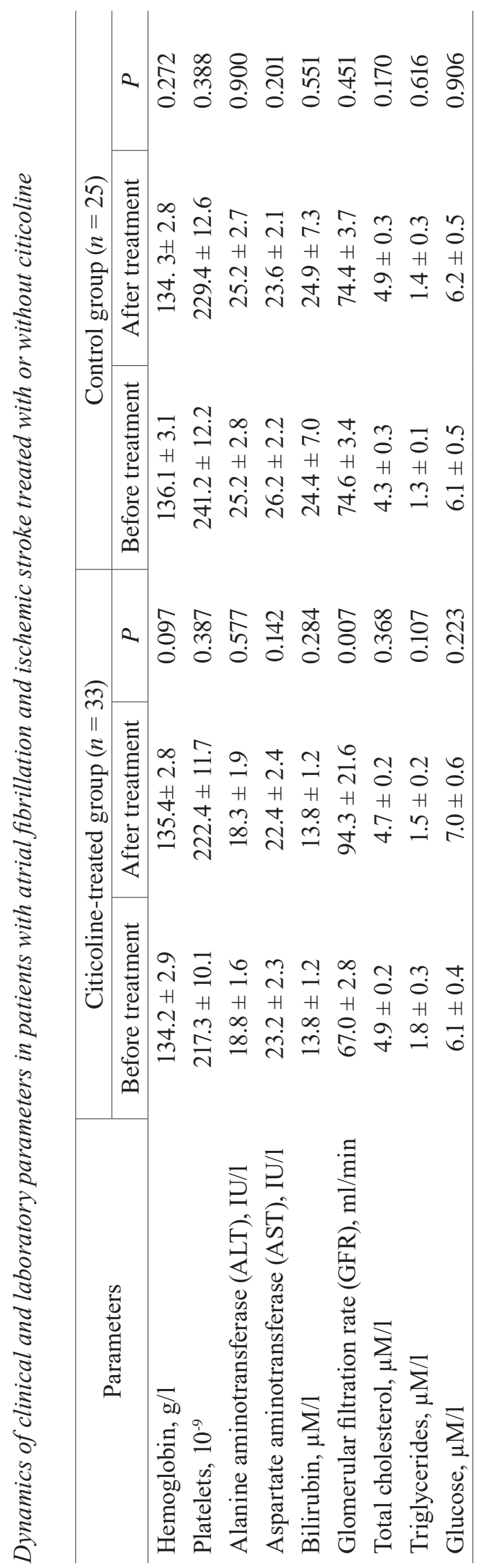

trol group (Figs. 2-4). Based on these findings, it can be assumed that CDP-choline action protects both astrocytes and neurons and specifically affects the pattern of angiogenesis regulation in the ischemiainjured brain.

Although ischemic stroke is considered a complex disease, approximately $20 \%$ of ischemic stroke cases develop due to cardiac embolism caused mainly by atrial fibrillation $[5,6]$. To the best of our knowledge, this is the first study to evaluate the roles of several neuronal and glial cytoskeletal specific proteins and an angiogenesis suppressor (angiostatin) as markers of citicoline effects in patients with ischemic stroke as a complication of atrial fibrillation. Acute ischemic stroke is among the leading causes of death and long-term disability. Knowledge of the molecular mechanisms that contribute to neuronal damage or death as a result of stroke is an important issue in context of the development of effective neuroprotective strategies. Ischemic cascade initiated by acute stroke eventually causes neuronal death resulting in an irreversible loss of neuronal function. Current therapeutic strategies in stroke generally include restoration of cerebral blood flow and the minimization of the harmful effects of ischemia on neurons. Intense research spanning the past two decades has witnessed significant therapeutic advances in the form of carotid endarterectomy, thrombolytics, anticoagulant therapy, antiplatelet agents, and neuroprotective drugs [7]. However, the most conventional treatment for ischemic stroke is limited to thrombolytics such as recombinant tissue plasminogen activator (rtPA) and antiplatelet drugs. For example, rtPA has a very narrow therapeutic window, making it suitable for only a minority of stroke patients [35]. Hence, there is great urgency to develop new therapies that can protect brain tissue from ischemic damage.

Citicoline, being the precursor of key ultrastructural components of the cellular membrane (mainly phospholipids), possesses a wide range of activities, promotes restoration of the damaged cell membranes, suppresses action of phospholipases, prevents excessive formation of free radicals and destruction of cells, and inhibits the mechanisms of apoptosis. In the acute period of stroke, it reduces the volume of damaged tissue and improves cholinergic transmission. In head injury, it reduces the duration of post-traumatic coma and intensity of neurologic symptoms. Citicoline improves symptoms observed during hypoxia, such as memory impairment, emo- 

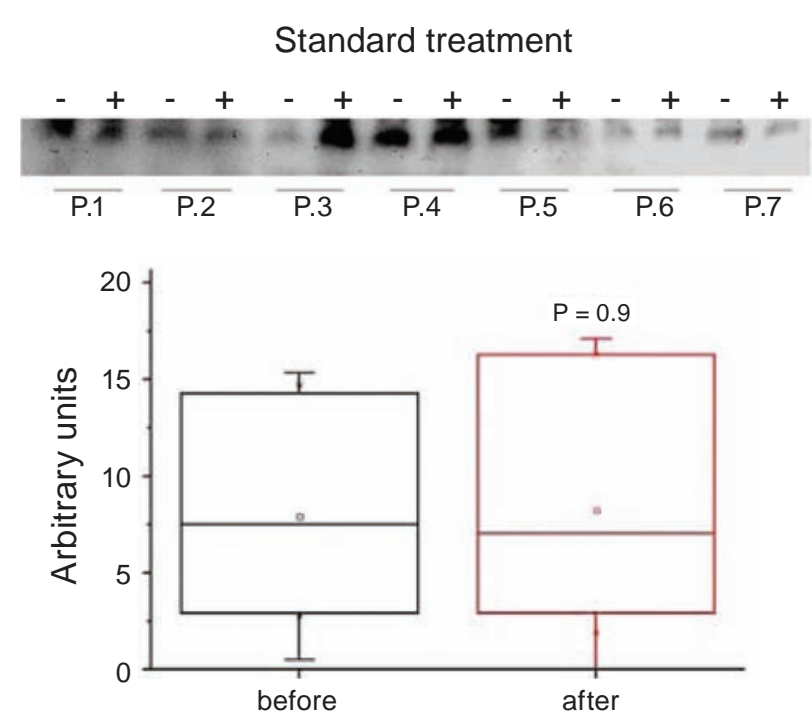

\section{Citicoline treatment}
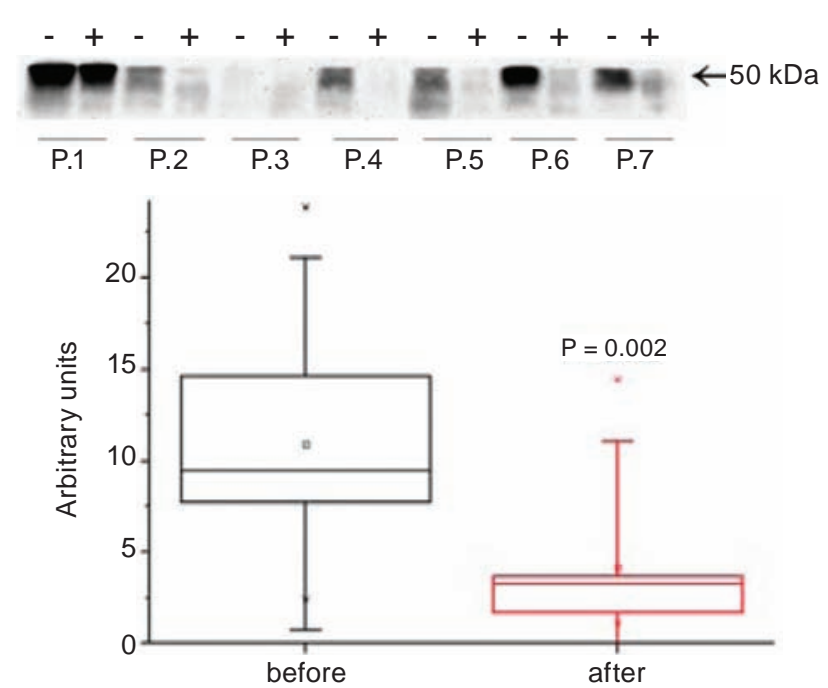

Fig. 2. Representative immunoblotting of glial fibrillary acidic protein (GFAP) in serum samples of patients with acute ischemic stroke and atrial fibrillation before (-) and after treatment ( + ) without (left panel, $n=25$ ) or with citicoline (right panel, $n=33)(P<0.05$ considered significant, paired t-test)

Standard treatment

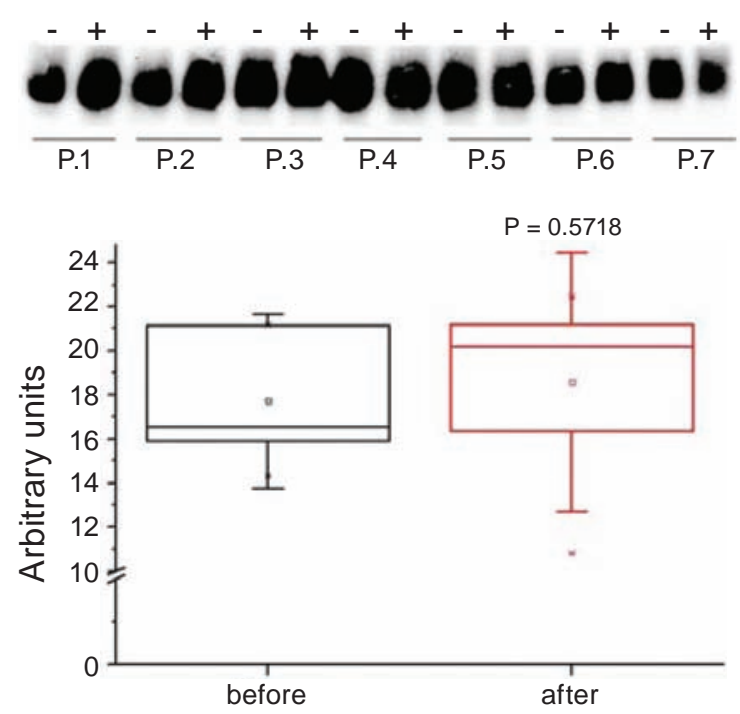

Citicoline treatment
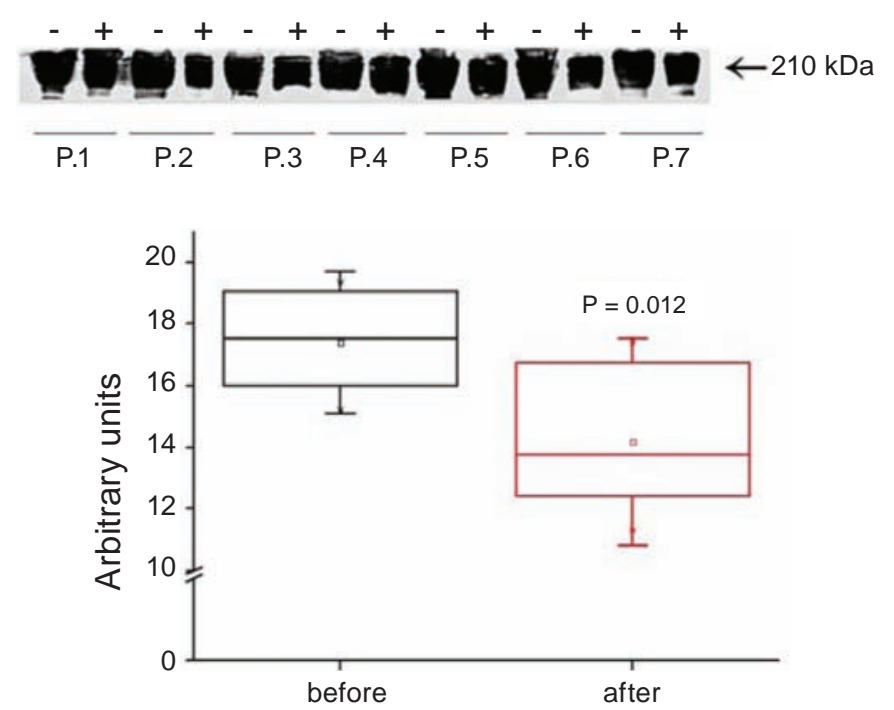

Fig. 3. Representative immunoblotting of neurofilament heavy subunit (NF-H) in serum samples of patients with acute ischemic stroke and atrial fibrillation before (-) and after treatment ( + ) without (left panel, $n=25)$ or with citicoline (right panel, $n=33)(P<0.05$ considered significant, paired $t$-test)

tional ability, lack of initiative, difficulties in conducting daily activities and self-care $[10,11]$.

Citicoline is one of the novel neuroprotective agents used as a therapy in stroke patients. Nevertheless, there are limited published reports describing the molecular mechanisms through which it acts, and reliable molecular markers of citicoline action remain undiscovered. The data of in vitro studies
[36] have shown that citicoline protects human brain microvascular endothelial cells (hCMEC/D3) against apoptosis and excitotoxic damage, strongly induces angiogenesis and significantly increases vascularisation in stroke affected regions of rats following the model of middle cerebral artery occlusion (MCAO) through a signalling pathway involving activation of the insulin-receptor-substrate-1. Another study 


\section{Standard treatment}
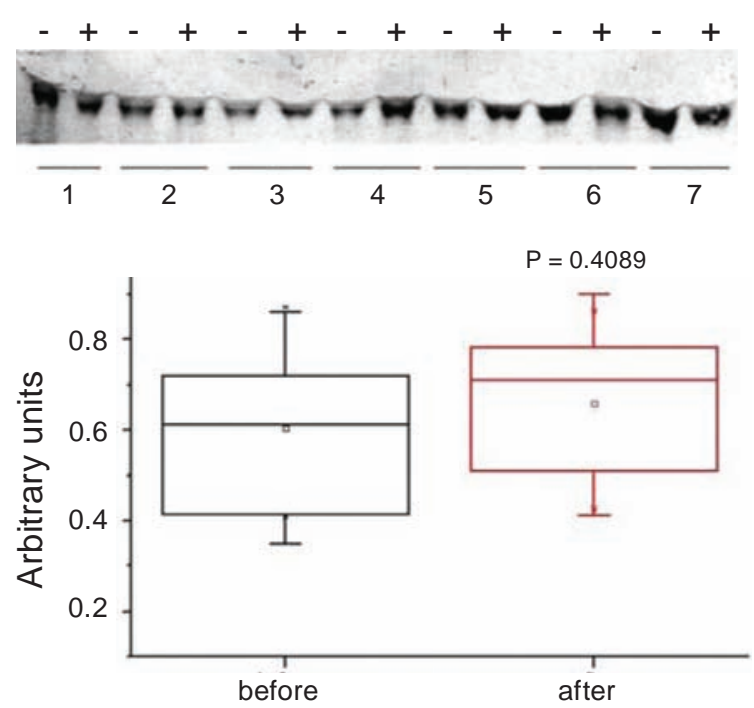

Citicoline treatment
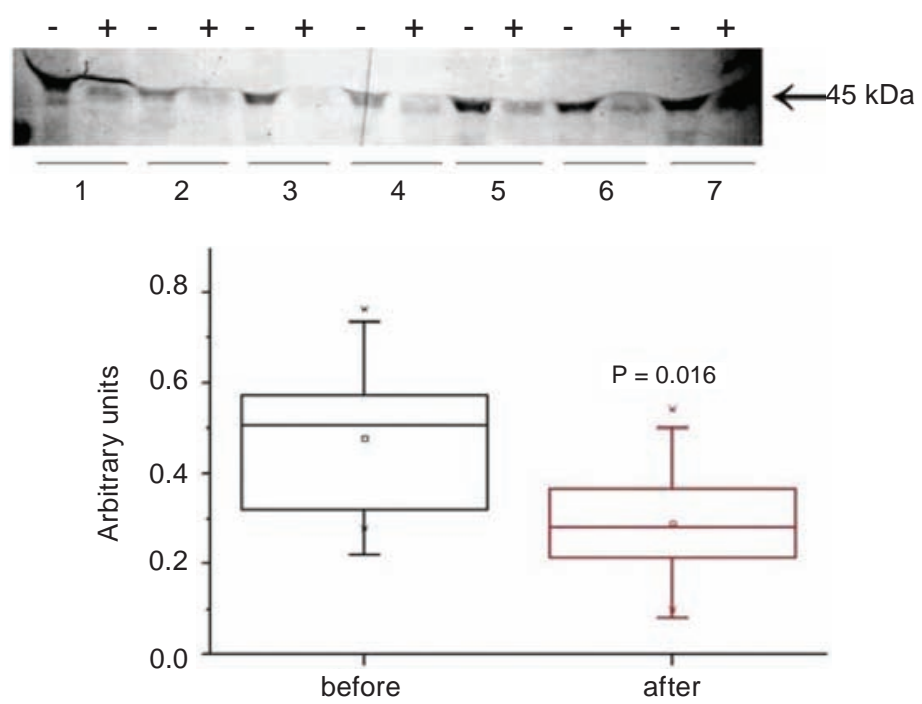

Fig. 4. Representative immunoblotting of angiostatin (AS) in serum samples of patients with acute ischemic stroke and atrial fibrillation before (-) and after treatment (+) without (left panel, $n=25$ ) or with citicoline (right panel, $n=33)(P<0.05$ considered significant, paired t-test)
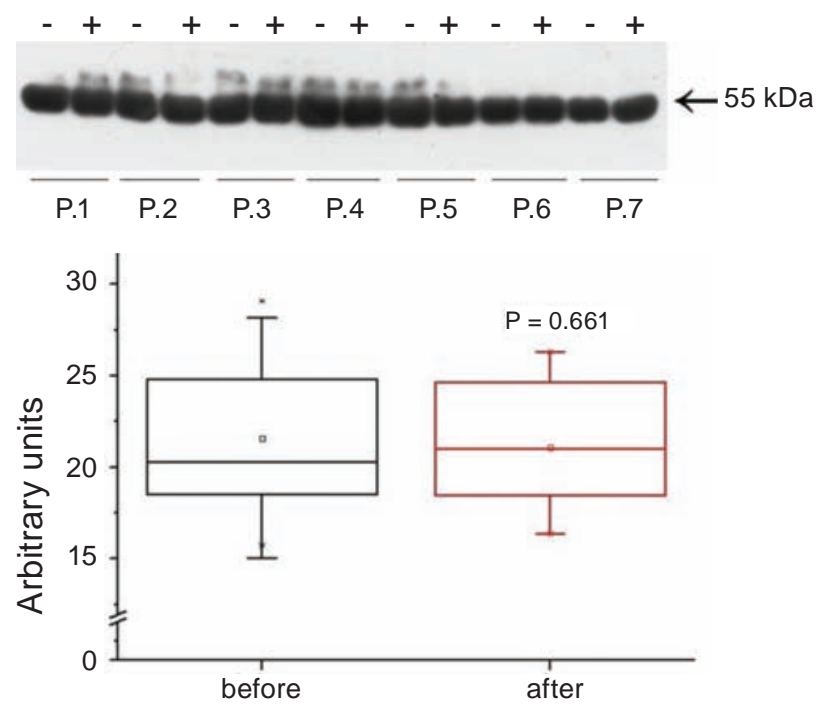

Fig. 5. Representative immunoblotting of human serum albumin (HSA) in serum samples $(n=33)$ of patients with acute ischemic stroke and atrial fibrillation before (-) and after citicoline treatment (+) $(P<0.05$ considered significant, paired $t$-test $)$

[25] indicates that CDP-choline improves functional recovery after permanent MCAO in association with reductions in lesion volume, cell death and low density lipoprotein receptor-related protein (LRP) expression. Moreover, CDP-choline increased cell proliferation, vasculogenesis and synaptophysin levels and reduced GFAP levels in the peri-infarct area of the ischemic stroke. It is known that endothelial progenitor cells (EPC) augment collateralization, increase capillary density, and enhance neurorepair and neurogenesis after experimental cerebral ischemia. A higher increment in EPC during the first week in patients with lacunar stroke is associated with a better functional outcome. Administration of 2,000 mg of citicoline from the first day of ischemic lacunar stroke led to a significant increase in circulating EPC by day 7 compared with non-treated patients and a better clinical outcome [8]. Based on these results, we decided to evaluate a plausible marker role of several proteins that might be associated with ischemic stroke and mediated effects of citicoline treatment.

The brain-specific astroglial protein GFAP and the triplet of NF proteins are well-characterized specific proteins of nervous tissue. GFAP represents a major part of the astrocytic cytoskeleton forming intermediate filament (astrofibrils) [37]. In the injured nervous system, astrocytes acquire a reactive phenotype and rapidly express GFAP, which can enter the blood due to the cell damage of BBB disruption [17]. Therefore, serum GFAP can be utilized as a marker of astrocytic reactivity levels. Some researchers have shown that GFAP levels increase in patients with acute cerebral infarction and that this increase is proportional to the extent of the lesion and the severity of the infarct $[16,18]$. Analogically, serum NF 
proteins, expressed exclusively in neurons, are blood biomarker candidates indicative of neuronal atrophy and axonal injury occurring in various neurodegenerative conditions and brain traumas [20]. Structural destruction of neural cells and leakage through the BBB into the bloodstream is a prerequisite for detectable NF release in peripheral blood. It has been demonstrated that serum NF levels are significantly increased in individuals with acute cerebral infarction compared with normal controls [21]. It is also important that measurement of GFAP and NF content in blood has possibilities as a relatively non-invasive means to identify acute damage to the CNS. Taking into consideration these facts, we selected GFAP and NF as two valid molecular markers of ischemic stroke injury. This study addresses whether citicoline would affect their serum levels reflecting outcome of therapy. Citicoline was shown to reduce serum levels of both studied CNS markers, but its effects on GFAP release appeared to be more profound. This important observation suggests that CDP-choline primarily affects astroglial cells in the injured brain. Considering the role of astrocytes in maintaining BBB integrity, the obtained results indicate that the decreased secretion level of GFAP can be a result of restriction of astroglial reactivity and partial recovery of BBB integrity. Other authors [11] have shown that the neuroprotective effect of citicoline may result from a dual action on both neurons and astrocytes. They have discovered that citicoline can display neuroprotection through decreasing brain glutamate release after ischemia. We found only minor, though statistically significant, citicoline-induced lowering in NF-H circulating levels. The axonal form of NF-H is heavily phosphorylated and resistant to proteolysis [38]. Since NF-H is found only in axons, its detection in blood points unambiguously to the release of this protein from axons and thus it can be utilized to assess disease activity and, potentially, therapeutic efficacy.

Our observations indicate that citicoline can protect neuronal cells against ischemic-mediated damage and prevents axonal degeneration. One of the possible mechanisms of citicoline neuroprotection may be improvement of angiogenic capacity and restoration of brain circulation. Angiogenesis is a key feature of the post-stroke neurovascular remodeling, and newly formed vessels may provide a scaffold for the migration of neural and glial progenitor cells toward the post-ischemic area. The effect of angiogenesis is to increase collateral circulation to meet the metabolic demands in terms of oxygen, glucose and nutrients required by the damaged and repaired tissues. Also, the newly generated blood vessels provide the neurotrophic support required by neurogenesis and synaptogenesis that eventually lead to functional recovery [39]. Overall, angiogenesis provides the stimulation required to launch and enhance endogenous mechanisms of repair and recovery including neurogenesis and synaptogenesis, as well as neuronal and synaptic plasticity. Poor collateral blood flow is associated with worse outcome and prognostication of patients and faster growth of larger infarcts in acute stroke. Therefore, collateral flow is a target for acute stroke treatment. Therapeutic promotion of collateral flow theoretically offers the chance for outcome improvement [40].

Angiogenesis is tightly controlled by the balance of two sets of counteracting factors - angiogenic activators and inhibitors. Angiogenic and anti-angiogenic regulators often co-exist in tissues with angiogenesis. These molecules can be secreted by endothelial, stromal, and blood cells into the extracellular matrix. VEGF is considered to be the main proangiogenic factor. Antiangiogenic factors include angiostatin, endostatin, thrombospondin 1, and endothelial monocyte-activating polypeptide 2 . However, in ischemic brain, the tight regulation of the balance of expression of these molecules can be disrupted resulting in suppression of angiogenesis and collateral formation [41]. In addition, enzymes such as serine proteinases and metalloproteinases (MMPs) destroy the extracellular matrix, and this event plays an important role in both induction and suppression of angiogenesis. Previous studies have demonstrated an abnormally high expression and activity of MMP-2 (gelatinase A) and/or MMP-9 (gelatinase B) after cerebral ischemia and in lipopolysaccharide-injured brains that contribute to brain injury and BBB breakdown [42, 43]. In addition, MMPs are responsible for angiostatin formation through limited cleavage of the precursor protein plasminogen [27]. Gundogdu et al. [44] have previously shown CDP-choline treatment to decrease the levels and activities of MMP-2 and MMP-9 and stimulate axonal regeneration in peripheral nerve injury. It is unknown if citicoline can affect MMP activities in the CNS, but this mechanism for modulation of angiostatin formation should be the object for future studies.

Initially, angiostatin has been found to exhibit an inhibitory effect on tumor growth acting as an 
anti-angiogenic factor [45]. Angiostatin plays a role in the local balance of angiogenesis and shows potent anti-angiogenic activity by suppressing proliferation and migration of endothelial cells as well as by inducing endothelial cell apoptosis [26]. Elevated angiostatin levels in patients with coronary artery disease have been recently demonstrated to correlate significantly with reduced angiogenesis and poorly developed cardiac collateral vasculature [46]. Local and systemic angiostatin up-regulation takes place in hyperglycemia, metabolic syndrome, several autoimmune disorders, and inflammatory processes, thereby sustaining associated vascular complications [28, 47-49]. Our recent data are in line with the above-mentioned reports because we have revealed that simvastatin lipid-lowering treatment of patients with ischemic heart disease results in the dramatic decrease of serum angiostatin that correlates significantly with the anti-inflammatory and anti-atherogenic effects of statin therapy [30]. There is lack of information about angiostatin production and its role in nervous tissue. To our knowledge, no studies on the function of angiostatin in acute ischemic stroke have been performed. However, we have recently discovered angiostatin isoforms in brain tissue of rats and have found that astrocytes are able to constistently produce angiostatins [50]. Our present investigation reveals that citicoline treatment of patients with acute ischemic stroke decreased anti-angiogenic signalling, specifically implicating angiostatin. Altogether, results obtained in our study open promising perspectives in pharmacological correction of conditions associated with angiopathies and poor pro-angiogenic signalling.

The present study has several limitations. First, larger clinical studies are needed to confirm these results. Second, detection of other neurochemical markers (neuron-specific enolase, S-100b, myelin basic protein) in serum would allow elucidating whether such an increase is primarily caused by neuronal damage or impaired BBB function. Third, this investigation assessed only one anti-angiogenic factor, angiostatin, while analysis of other suppressors and concurrent mediators would be desirable to evaluate the total balance of angiogenesis regulators. And last, longitudinal follow-up data were not available to test associations between the serum levels of biomarkers and clinical outcomes.

In conclusion, citicoline treatment of patients with atrial fibrillation and ischemic stroke leads to diminished release of astroglial and neuronal spe- cific proteins into the blood and down-regulation of serum angiostatin levels. These results indicate that citicoline acts as a neuroprotector through defending brain cells against ischemia-induced destruction and improving angiogenic potential. Further studies are needed to draw definite conclusions about possible roles for angiostatin as a valuable marker for the diagnosis and stratification of stroke patients, as well as a therapeutic target.

Competing interests. No pharmaceutical companies influenced the treatment conditions, study design, data collection and analysis, preparation of the manuscript, or choice of the journal.

\section{ВПЛИВ ЦИТИКОЛІНУ НА ВМІСТ АНГІОСТАТИНУ ТА НЕЙРОСПЕЦИФІЧНИХ ПРОТЕЇНІВ У СИРОВАТЦІ КРОВІ ПАЦІЕНТІВ ІЗ ФІБРИЛЯЦІЕЮ ПЕРЕДСЕРДЬ ТА ІШЕМІЧНИМ ІНСУЛЬТОМ}
А. О. Тихомиров ${ }^{1 \bowtie}$ Ю. С. Кушнір ${ }^{2}$,
В. С. Недзвецький , Т. В. Гриненко
О. В. Курята ${ }^{2}$

${ }^{1}$ Інститут біохімії ім. О. В. Палладіна, НАН України, Київ;

${ }^{2}$ ДЗ «Дніпропетровська медична академія МO3 України», Дніпро;

${ }^{3}$ Бінгольський університет, Бінгол, Туреччина; 凶e-mail: artem_tykhomyrov@ukr.net

Ішемічний інсульт $є$ одним із найпоширеніших і важких ускладнень фібриляції передсердь. Метою представленої роботи було визначити вплив цитидин дифосфатхоліну (ЦДФ, або цитиколіну) на вміст інгібітора ангіогенезу ангіостатину та нейроспецифічних протеїнів як маркерів пошкодження головного мозку у післяінсультних пацієнтів із фібриляцією передсердь. Пацієнти 3 діагнозом гострий ішемічний інсульт $(n=33)$ отримували цитиколін натрію у вигляді внутрішньовенних ін'єкцій (1 г/доба протягом 14 днів) у доповнення до стандартного лікування (основна група). Пацієнти 3 тією ж патологією $(n=25)$, які проходили стандартний курс лікування, становили контрольну групу. Вміст ангіостатину та нейроспецифічних протеїнів, а саме важкої субодиниці нейрофіламентів (NF-H) i гліального фібрилярного кислого протеїну (GFAP), визначали за допомогою імуноблотингу в сироватці крові до та після лікування. Показа- 
но, що лікування із застосуванням цитиколіну істотно зменшило вміст ангіостатину (на $40 \%$ у порівнянні з базальним рівнем, $P<0,05)$, GFAP (на $61 \%, P<0,01$ ), NF-H (на $19 \%, P<0,05$ ) та не впливало на рівень сироваткового альбуміну. На противагу цьому, в пацієнтів контрольної групи статистично вірогідних змін вмісту досліджуваних протеїнів після курсу стандартного лікування не спостерігалося. Одержані в дослідженні результати вказують на те, що ЦДФ-холін виявляє захисну дію по відношенню до астроцитів та нейронів, а також покращує ангіогенний потенціал за рахунок пригнічення утворення ангіостатину у післяінсультних пацієнтів з фібриляцією передсердь. Подальших досліджень потребують питання про зв'язок між вмістом біомаркерів у сироватці, клінічними проявами та ефективністю лікування інсульту.

К л ю ч о в і с л о в а: фібриляціяпередсердь, ішемічний інсульт, цитиколін, ангіостатин, нейрофіламенти, гліальний фібрилярний кислий протеїн.

\section{References}

1. Son MK, Lim NK, Kim HW, Park HY. Risk of ischemic stroke after atrial fibrillation diagnosis: a national sample cohort. PLoS One. 2017; 12(6): e0179687.

2. Morley J, Marinchak R, Rials SJ, Kowey P. Atrial fibrillation, anticoagulation, and stroke. Am J Cardiol. 1996; 77(3): 38A-44A.

3. Saposnik G, Gladstone D, Raptis R, Zhou L, Hart RG. Atrial fibrillation in ischemic stroke: predicting response to thrombolysis and clinical outcomes. Stroke. 2013; 44(1): 99-104.

4. Yang PS, Pak HN, Park DH, Yoo J, Kim TH, Uhm JS, Kim YD, Nam HS, Joung B, Lee MH, Heo JH. Non-cardioembolic risk factors in atrial fibrillation-associated ischemic stroke. PLoS One. 2018; 13(7): e0201062.

5. Pulit SL, Weng LC, McArdle PF, Trinquart L, Choi SH, Mitchell BD, Rosand J, de Bakker PIW, Benjamin EJ, Ellinor PT, Kittner SJ, Lubitz SA, Anderson CD. Atrial fibrillation genetic risk differentiates cardioembolic stroke from other stroke subtypes. Neurol Genet. 2018; 4(6): e293.

6. Santos JV, Pereira J, Pinto R, Castro PM, Azevedo E, Freitas A. Atrial fibrillation as an ischemic stroke clinical and economic burden modifier: a 15-year nationwide study. Value Health. 2017; 20(8): 1083-1091.
7. Wang J, Yang W, Xie H, Song Y, Li Y, Wang L. Ischemic stroke and repair: current trends in research and tissue engineering treatments. Regen Med Res. 2014; 2(1): 3.

8. Alvarez-Sabín J, Román GC. The role of citicoline in neuroprotection and neurorepair in ischemic stroke. Brain Sci. 2013; 3(3): 1395-1414.

9. Gareri P, Castagna A, Cotroneo AM, Putignano S, De Sarro G, Bruni AC. The role of citicoline in cognitive impairment: pharmacological characteristics, possible advantages, and doubts for an old drug with new perspectives. Clin Interv Aging. 2015; 10: 1421-1429.

10. Secades JJ, Alvarez-Sabín J, Castillo J, Díez-Tejedor E, Martínez-Vila E, Ríos J, Oudovenko N. Citicoline for acute ischemic stroke: a systematic review and formal metaanalysis of randomized, double-blind, and placebo-controlled trials. J Stroke Cerebrovasc Dis. 2016; 25(8): 1984-1996.

11. Hurtado O, Moro MA, Cárdenas A, Sánchez V, Fernández-Tomé P, Leza JC, Lorenzo $\mathrm{P}$, Secades JJ, Lozano R, Dávalos A, Castillo J, Lizasoain I. Neuroprotection afforded by prior citicoline administration in experimental brain ischemia: effects on glutamate transport. Neurobiol Dis. 2005; 18(2): 336-345.

12. Martynov MY, Gusev EI. Current knowledge on the neuroprotective and neuroregenerative properties of citicoline in acute ischemic stroke. J Exp Pharmacol. 2015; 7: 17-28.

13. Wang Q, Tang XN, Yenari MA. The inflammatory response in stroke. J Neuroimmunol. 2007; 184(1-2): 53-68.

14. Glushakova OY, Glushakov AV, Miller ER, Valadka AB, Hayes RL. Biomarkers for acute diagnosis and management of stroke in neurointensive care units. Brain Circ. 2016; 2(1): 28-47.

15. Kawata K, Liu CY, Merkel SF, Ramirez SH, Tierney RT, Langford D. Blood biomarkers for brain injury: what are we measuring? Neurosci Biobehav Rev. 2016; 68: 460-473.

16. Koz ST, Baydas G, Koz S, Demir N, Nedzvetsky VS. Gingko biloba extract inhibits oxidative stress and ameliorates impaired glial fibrillary acidic protein expression, but can not improve spatial learning in offspring from hyperhomocysteinemic rat dams. Phytother Res. 2012; 26(7): 949-955. 
17. Liddelow SA, Barres BA. Reactive astrocytes: production, function, and therapeutic potential. Immunity. 2017; 46(6): 957-967.

18. Katsanos AH, Makris K, Stefani D, Koniari K, Gialouri E, Lelekis M, Chondrogianni M, Zompola C, Dardiotis E, Rizos I, Parissis J, Boutati E, Voumvourakis K, Tsivgoulis G. Plasma glial fibrillary acidic protein in the differential diagnosis of intracerebral hemorrhage. Stroke. 2017; 48(9): 2586-2588.

19. Yuan A, Rao MV, Veeranna, Nixon RA. Neurofilaments and neurofilament proteins in health and disease. Cold Spring Harb Perspect Biol. 2017; 9(4): a018309.

20. Traenka C, Disanto G, Seiffge DJ, Gensicke H, Hert L, Grond-Ginsbach C, Peters N, Regeniter A, Kloss M, De Marchis GM, Bonati LH, Lyrer PA, Kuhle J, Engelter ST. Serum neurofilament light chain levels are associated with clinical characteristics and outcome in patients with cervical artery dissection. Cerebrovasc Dis. 2015; 40(5-6): 222-227.

21. Pujol-Calderón F, Portelius E, Zetterberg H, Blennow $\mathrm{K}$, Rosengren LE, Höglund $\mathrm{K}$. Neurofilament changes in serum and cerebrospinal fluid after acute ischemic stroke. Neurosci Lett. 2019; 698: 58-63.

22. Xiong XY, Liu L, Yang QW. Refocusing neuroprotection in cerebral reperfusion era: new challenges and strategies. Front Neurol. 2018; 9: 249.

23. Cosky EEP, Ding Y. The role of vascular endothelial growth factor in angiogenesis and brain circulation after stroke. Brain Circ. 2018; 4(2): 73-75.

24. Berntsson J, Smith JG, Johnson LSB, Söderholm M, Borné Y, Melander O, OrhoMelander M, Nilsson J, Engström G. Increased vascular endothelial growth factor $\mathrm{D}$ is associated with atrial fibrillation and ischaemic stroke. Heart. 2019; 105(7): 553-558.

25. Gutiérrez-Fernández M, Rodríguez-Frutos B, Fuentes B, Vallejo-Cremades MT, AlvarezGrech J, Expósito-Alcaide M, Díez-Tejedor E. CDP-choline treatment induces brain plasticity markers expression in experimental animal stroke. Neurochem Int. 2012; 60(3): 310-317.

26. Lee TY, Muschal S, Pravda EA, Folkman J, Abdollahi A, Javaherian K. Angiostatin regulates the expression of antiangiogenic and proapoptotic pathways via targeted inhibition of mitochondrial proteins. Blood. 2009; 114(9): 1987-1998.

27. Chung AW, Hsiang YN, Matzke LA, McManus BM, van Breemen C, Okon EB. Reduced expression of vascular endothelial growth factor paralleled with the increased angiostatin expression resulting from the upregulated activities of matrix metalloproteinase-2 and -9 in human type 2 diabetic arterial vasculature. Circ Res. 2006; 99(2): 140-148.

28. Sodha NR, Clements RT, Boodhwani M, Xu SH, Laham RJ, Bianchi C, Sellke FW. Endostatin and angiostatin are increased in diabetic patients with coronary artery disease and associated with impaired coronary collateral formation. Am J Physiol Heart Circ Physiol. 2009; 296(2): H428-434.

29. El-Ashmawy HM, Roshdy HS, Saad Z, Ahmed AM. Serum endostatin level as a marker for coronary artery calcification in type 2 diabetic patients. J Saudi Heart Assoc. 2019; 31(1): 24-31.

30. Tykhomyrov AA, Nedzvetsky VS, Bardachenko NI, Grinenko TV, Kuryata OV. Statin treatment decreases serum angiostatin levels in patients with ischemic heart disease. Life Sci. 2015; 134: 22-29.

31. Tykhomyrov AA, Nedzvetsky VS, Zabida AA, Ağca CA, Kuryata OV. 1-Arginine treatment improves angiogenic response and reduces matrix metalloproteinase activity in chronic heart failure patients with coronary artery disease. PharmaNutrition. 2018; 6(4): 137-146.

32. Tykhomyrov AA, Yusova EI, Diordieva SI, Corsa VV, Grinenko TV. Production and characteristics of antibodies against K1-3 fragment of human plasminogen. Biotechnologia Acta. 2013; 6(1): 87-97.

33. Stoscheck CM. Quantitation of protein. Methods Enzymol. 1990; 182: 50-68.

34. Tykhomyrov AA, Nedzvetsky VS, Klochkov VK, Andrievsky GV. Nanostructures of hydrated $\mathrm{C}_{60}$ fullerene $\left(\mathrm{C}_{60} \mathrm{HyFn}\right)$ protect rat brain against alcohol impact and attenuate behavioral impairments of alcoholized animals. Toxicology. 2008; 246 (2-3): 158-165.

35. Berge E, Cohen G, Roaldsen MB, Lundström E, Isaksson E, Rudberg AS, Slot KB, Forbes J, Smith J, Drever J, Wardlaw JM, Lindley RI, Sandercock PA, Whiteley WN; IST-3 
Collaborative Group. Effects of alteplase on survival after ischaemic stroke (IST-3): 3 year follow-up of a randomised, controlled, openlabel trial. Lancet Neurol. 2016; 15(10): 10281034.

36. Krupinski J, Abudawood M, Matou-Nasri S, AlBaradie R, Petcu EB, Justicia C, Planas A, Liu D, Rovira N, Grau-Slevin M, Secades J, Slevin M. Citicoline induces angiogenesis improving survival of vascular/human brain microvessel endothelial cells through pathways involving ERK1/2 and insulin receptor substrate-1. VasC Cell. 2012; 4(1): 20.

37. Jickling GC, Sharp FR. Biomarker panels in ischemic stroke. Stroke. 2015; 46(3): 915-920.

38. Anderson KJ, Scheff SW, Miller KM, Roberts KN, Gilmer LK, Yang C, Shaw G. The phosphorylated axonal form of the neurofilament subunit NF-H (pNF-H) as a blood biomarker of traumatic brain injury. J Neurotrauma. 2008; 25(9): 1079-1085.

39. Sawada M, Matsumoto M, Sawamoto K. Vascular regulation of adult neurogenesis under physiological and pathological conditions. Front Neurosci. 2014; 8: 53.

40. Jung S, Wiest R, Gralla J, McKinley R, Mattle H, Liebeskind D. Relevance of the cerebral collateral circulation in ischaemic stroke: time is brain, but collaterals set the pace. Swiss Med Wkly. 2017; 147: w14538.

41. Liu J, Wang Y, Akamatsu Y, Lee CC, Stetler RA, Lawton MT, Yang GY. Vascular remodeling after ischemic stroke: mechanisms and therapeutic potentials. Prog Neurobiol. 2014; 115: 138-156.

42. Montaner J, Alvarez-Sabín J, Molina CA, Anglés A, Abilleira S, Arenillas J, Monasterio J. Matrix metalloproteinase expression is related to hemorrhagic transformation after cardioembolic stroke. Stroke. 2001; 32(12): 2762-2767.

43. Rosell A, Cuadrado E, Ortega-Aznar A, Hernández-Guillamon M, Lo EH, Montaner J. MMP-9-positive neutrophil infiltration is associated to blood-brain barrier breakdown and basal lamina type IV collagen degradation during hemorrhagic transformation after human ischemic stroke. Stroke. 2008; 39(4): 1121-1126.

44. Gundogdu EB, Bekar A, Turkyilmaz M, Gumus A, Kafa IM, Cansev M. CDP-choline modulates matrix metalloproteinases in rat sciatic injury. J Surg Res. 2016; 200(2): 655-663.

45. O'Reilly MS, Holmgren L, Shing Y, Chen C, Rosenthal RA, Cao Y, Moses M, Lane WS, Sage EH, Folkman J. Angiostatin: a circulating endothelial cell inhibitor that suppresses angiogenesis and tumor growth. Cold Spring Harb Symp Quant Biol. 1994; 59: 471-482.

46. Matsunaga T, Chilian WM, March K. Angiostatin is negatively associated with coronary collateral growth in patients with coronary artery disease. Am J Physiol Heart Circ Physiol. 2005; 288(5): H2042-2046.

47. Dodd T, Wiggins L, Hutcheson R, Smith E, Musiyenko A, Hysell B, Russell JC, Rocic P. Impaired coronary collateral growth in the metabolic syndrome is in part mediated by matrix metalloproteinase 12-dependent production of endostatin and angiostatin. Arterioscler Thromb Vasc Biol. 2013; 33(6): 1339-1349.

48. Keskin D, Keskin G, Inal A, Ozışık L. Serum angiostatin levels in patients with Behçet's disease: does angiogenesis play a role in the pathogenesis of Behçet's disease? Acta Clin Belg. 2014; 69(4): 246-250.

49. Kotulska-Kucharz A, Kopeć-Mędrek M, Kucharz EJ. Serum angiostatin and endostatin levels in patients with granulomatosis with polyangiitis and immune complex small vessel vasculitis. Reumatologia. 2018; 56(5): 285-288.

50. Tykhomyrov AA, Nedzvetsky VS, Ağca CA, Korsa VV, Grinenko TV. Plasminogen and its fragments in rat brain: a plausible role for astrocytes in angiostatin generation. $U k r$ Biochem J. 2017; 89(2): 43-54. 